Bird Study

\title{
Ecological correlates of Golden Eagle Aquila chrysaetos breeding occurrence in Sardinia
}

M. Di Vittorio, M. Medda, G. Sirigu, L. Luiselli, G. Manca, S. Nissardi, C. Zucca, D. Ruiu, A. Brau, M. Sanna, M. Grussu, A. Campus, F. Spina, L. Serra, E. Raganella Pelliccioni, A. Marcon, V. Asuni, A. Fadda, A. Secci, M. Corda, A. Lai \& P. López-López

To cite this article: M. Di Vittorio, M. Medda, G. Sirigu, L. Luiselli, G. Manca, S. Nissardi, C. Zucca, D. Ruiu, A. Brau, M. Sanna, M. Grussu, A. Campus, F. Spina, L. Serra, E. Raganella Pelliccioni, A. Marcon, V. Asuni, A. Fadda, A. Secci, M. Corda, A. Lai \& P. López-López (2020) Ecological correlates of Golden Eagle Aquila chrysaetos breeding occurrence in Sardinia, Bird Study, 67:4, 484-495, DOI: $10.1080 / 00063657.2021 .1948966$

To link to this article: https://doi.org/10.1080/00063657.2021.1948966

曲 Published online: 21 Jul 2021.

Submit your article to this journal $\llbracket$

Щ Article views: 35

Q View related articles $\sqsubset$

View Crossmark data $₫$ 


\title{
Ecological correlates of Golden Eagle Aquila chrysaetos breeding occurrence in Sardinia
}

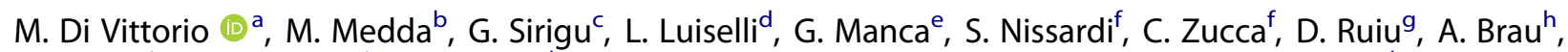

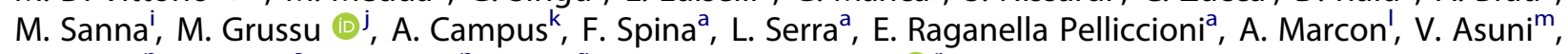 \\ A. Fadda ${ }^{n}$, A. Secci ${ }^{\circ}$, M. Corda ${ }^{p}$, A. Lai ${ }^{q}$ and P. López-López (i) ${ }^{r}$
}

\begin{abstract}
${ }^{a}$ Area Avifauna Migratrice, ISPRA, Ozzano Emilia, Italy; ${ }^{b}$ Independent Researcher, Cagliari, Italy; 'Independent Researcher, Quartu Sant'Elena, Italy; ${ }^{d}$ Department of Applied and Environmental Biology, Rivers State University of Science and Technology, PMB, Port Harcourt, Nigeria; ${ }^{\mathrm{e}}$ Independent Researcher, Loiri porto San Paolo, Italy; ${ }^{\mathrm{f}}$ Anthus sns, Cagliari, Italy; ${ }^{\mathrm{g}}$ Independent Researcher, Nuoro, Italy; ${ }^{\mathrm{h}}$ Independent Researcher, Oniferi, Italy; IIIndependent Researcher, Sassari, Italy; ${ }^{j}$ Gruppo Ornitologico Sardo, Quartu Sant'Elena, Italy; ${ }^{k}$ Associazione Naturalistica L'AltraBosa, Bosa, Italy; 'Area per l'epidemiologia, I'ecologia e la gestione della fauna stanziale e degli habitat, ISPRA, Ozzano Emilia, Italy; ${ }^{\mathrm{m}}$ Independent Researcher, Sinnai, Italy; ${ }^{\mathrm{n}}$ Independent Researcher, Capoterra, Italy; ${ }^{\circ}$ Independent Researcher, Villaspeciosa, Italy; ${ }^{\mathrm{p}}$ Independent Researcher, Dolianova, Italy; ${ }^{\mathrm{q}}$ Independent Researcher, Lula, Italy; ${ }^{\mathrm{r}}$ Cavanilles Institute of Biodiversity and Evolutionary Biology, Movement Ecology Lab, University of Valencia, Valencia, Spain
\end{abstract}

\begin{abstract}
Capsule: Golden Eagles Aquila chrysaetos in Sardinia are clustered across the main mountain ranges of the island, with a preference for undisturbed and homogeneous inland habitats.

Aims: To analyse habitat preferences of the Golden Eagle in Sardinia, Italy, at the landscape and home range spatial scales.

Methods: Landscape scale habitat preferences were analysed using the $10 \times 10 \mathrm{~km}$ Universal Transverse Mercator grid and the home range scale was based on the spatial distribution of breeding territories. Generalized linear models were fitted with three different sets of environmental predictors (topographic, bioclimatic and land use variables) to analyse the spatial distribution of Golden Eagles with a case-control design.

Results: Eagles showed a preference for rugged and elevated areas, characterized by a certain degree of humidity and surrounded by areas of forest. The distribution of Golden Eagles on this Mediterranean island was negatively affected by the occurrence of arable farmland and coastal areas, as well as by the effects of habitat fragmentation.

Conclusions: The results of this study could contribute to future management strategies and conservation projects aimed to protect this species, and may be used to identify the most suitable conservation areas for this and other competing species, such as the Bonelli's Eagle Aquila fasciata, which is currently the subject of a reintroduction project in Sardinia.
\end{abstract}

ARTICLE HISTORY

Received 29 July 2020

Accepted 11 November 2020
The study of the relationship between the geographic distribution of a given species and the main features of its environment (e.g. topographic, landscape and climatic factors) is often quantified using predictive modelling (Guisan \& Zimmermann 2000) and is essential to guide appropriate conservation decisions (Larson et al. 2004, Nams et al. 2006). In recent decades, species distribution modelling has been commonly used to identify suitable habitat and to predict a potential distribution of target taxa (Robertson et al. 2003, Rushton et al. 2004, Matyukhina et al. 2015), with particular emphasis on threatened species (Guisan \& Zimmermann 2000).

The Golden Eagle Aquila chrysaetos is a raptor with a wide Holarctic distribution, that inhabits a large variety of habitats, especially mountain systems and uplands (Del Hoyo et al. 1994, Ferguson-Lees \& Christie 2001). Although the species suffered heavy persecution in the nineteenth century, its populations now appear stable throughout Europe and the species is listed as 'Least Concern' by the International Union for Conservation of Nature (BirdLife International 2017).

The Golden Eagle population in Italy currently consists of at least 622 breeding pairs (Fasce \& Fasce 2017). Although it shows a positive trend across the Italian peninsula (Brichetti \& Fracasso 2003, Fasce \& Fasce 2017), the species is listed as 'Near Threatened' on the Italian Red List (Rondinini et al. 2013). The Sardinian population has also increased, from an estimated population of 25-38 pairs in the 1970s (Schenk 1976) to 
40-50 pairs in the 1990s and 2000s (Schenk 1995, Asuni et al. 2003, Fasce \& Fasce 2003), and is currently estimated at 57-70 breeding pairs (Ruiu 2017, Fasce \& Fasce 2017, Sirigu et al. 2019). In Sardinia, unlike other Mediterranean populations, the Golden Eagle is demographically isolated and immigration from continental populations appears to be scarce and unlikely (authors' personal observations). Thus, knowledge of its ecological requirements at local level is essential for its conservation and useful to support the management of isolated populations in similar environments in other regions across the wide range of the species.

The aim of this paper is to analyse the habitat preferences of the Golden Eagle in Sardinia, with emphasis on investigating the environmental features that favour this important island population. Furthermore, the Golden Eagle is a potential competitor of the Bonelli's Eagle Aquila fasciata (GilSánchez et al. 1994, 1996, Del Hoyo et al. 1994, Carrete et al. 2001, 2002, 2005, López-López et al. 2004, Martí \& del Moral 2003, Real 2004, Martínez et al. 2007). Bonelli's Eagle disappeared from Sardinia at the end of the twentieth century, most likely due to illegal taking for the black market and direct persecution (RaganellaPelliccioni et al. 2018). The results of this study may also be important to evaluate the potential niche segregation between these two species, which could be of particular interest for the reintroduction project of Bonelli's Eagle currently underway in Sardinia (AQUILA a-LIFE, LIFE16 NAT/ES/000235).

\section{Methods}

A total of 56 breeding territories regularly occupied in 2019 by Golden Eagles was analysed, by using a casecontrol design (Hosmer \& Lemeshow 2000, Keating \& Cherry 2004) at two spatial scales: (i) Landscape scale, $(10 \times 10 \mathrm{~km}$, Universal Transverse Mercator (UTM) cells where the species was present or absent); and (ii) Home range scale, based on the spatial distribution of breeding territories, in $5 \mathrm{~km}$ radius plots centred at nesting sites. This measure is a conservative but reliable approximation of the core home range of Golden Eagles (Sergio et al. 2006, Haworth et al. 2010), particularly taking into account the movements of breeding Golden Eagles tracked by telemetry in Mediterranean areas (López-López, P. unpublished data).

\section{Measurement of habitat variables at the landscape scale}

For this analysis, we considered as occupied the 118 cells (UTM $10 \times 10 \mathrm{~km}$ squares) intersecting the plots of $5 \mathrm{~km}$ radius centred on the 56 Golden Eagle nesting sites occupied by the species. The remaining 193 cells encompassing Sardinia territory were considered as unoccupied $(N$ total $=311)$ (Figure 1$)$. Both occupied and unoccupied cells were sampled to record information on 18 environmental variables using Geographic Information System (GIS) software (Table 1). The variables were related to topography, land use and bioclimate. Land use variables were obtained from the CORINE Land cover map (https://land.copernicus. eu/pan-european/corine-land-cover/clc2018) at 1:25000 scale. At this scale, CORINE Land cover classes (CLCs) have been considered at the first CORINE hierarchic level (EEA 2000). Topographic variables were obtained

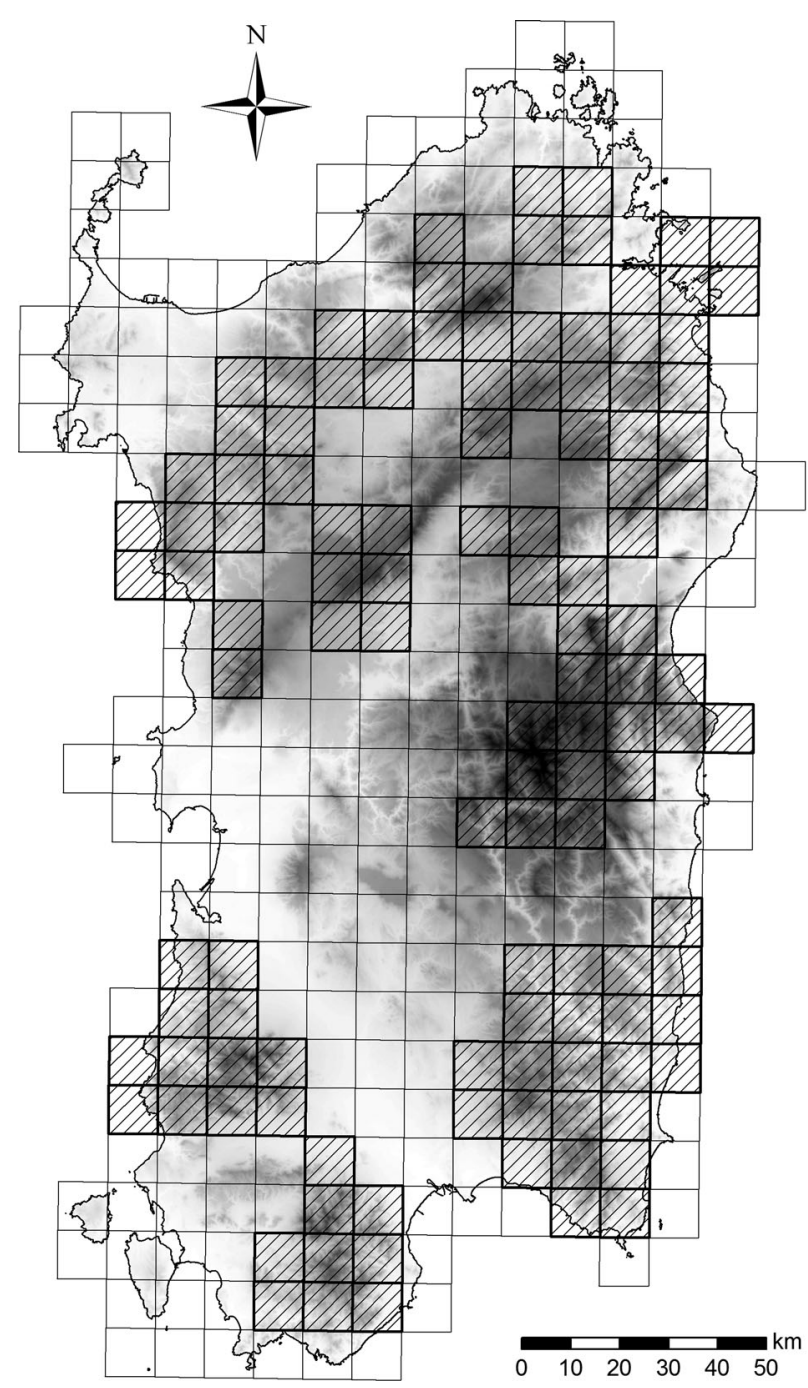

Figure 1. Distribution of the Golden Eagle in Sardinia, Italy, with the overlapping grid of Universal Transverse Mercator (UTM) $10 \times 10 \mathrm{~km}$ squares. Occupied cells are shaded with dashed lines. Background: Digital Elevation Model at 25-m horizontal resolution (source: Copernicus European Environment Agency; https://land.copernicus.eu/imagery-in-situ/eu-dem/eu-dem-v1. $1 /$ view). 
from a digital elevation model (DEM) with $10 \mathrm{~m}$ pixels of horizontal and vertical resolution. The bioclimatic ombrotype was obtained from the Annual Ombrothermic Index $\left(I_{\mathrm{o}}\right)$ (Canu et al. 2015). This index shows the average annual availability of water for plants by including the reduction in rainfall efficiency with increasing temperatures in its formula:

$$
I_{o}=\left(P_{p} / T_{p}\right)
$$

where $P_{p}$ is the total rainfall $(\mathrm{mm})$ of all months with positive average temperature and $T_{p}$ is the sum of the monthly average temperature $\left({ }^{\circ} \mathrm{C}\right)$ of all months with positive average temperature (Mesquita \& Sousa 2009).

\section{Measurement of habitat variables at the home range scale}

Nest sites and a subset of an equal number of randomly selected unoccupied points were geo-referenced on a GIS digital map. Circular plots with a radius equal to $5 \mathrm{~km}$ were then drawn around nest sites and unoccupied points to determine the minimum utilized home range (Sarà \& Di Vittorio 2003). Then, both occupied $(n=56)$ and control $(n=56)$ points were independently sampled to collect information on 23 variables using GIS software. Environmental predictors included land use and other variables describing habitat composition (Table 1). At this scale, CLCs were used according to the second hierarchical level (EEA 2000) except for artificial areas and inland waters, which were considered at the first level. The count, perimeter, surface and CLC of singles patches of all plots were obtained from the same digital map. The mosaic patterns were redrawn following Forman (1995) using the numbers, perimeters, surfaces and boundaries of patches of CLCs defined in Table 1.

\section{Statistical analysis}

In order to assess differences between habitat characteristics of Golden Eagle occupied and unoccupied cells at both landscape and home range scales, we compared the mean values of variables using univariate Mann-Whitney tests. To account for the effect of multiple comparisons we computed corrected $P$-values using the Benjamini-Hochberg multiple comparisons procedure for controlling the false discovery rate (Benjamini \& Hochberg 1995). In addition, we also computed statistics of effect size and $95 \%$ confidence intervals for the Mann-Whitney
Table 1. Explanatory variables used to characterize the habitat preferences of Golden Eagles at landscape and home range scales in Sardinia. The corresponding CORINE Land cover class code at two levels is shown in brackets.

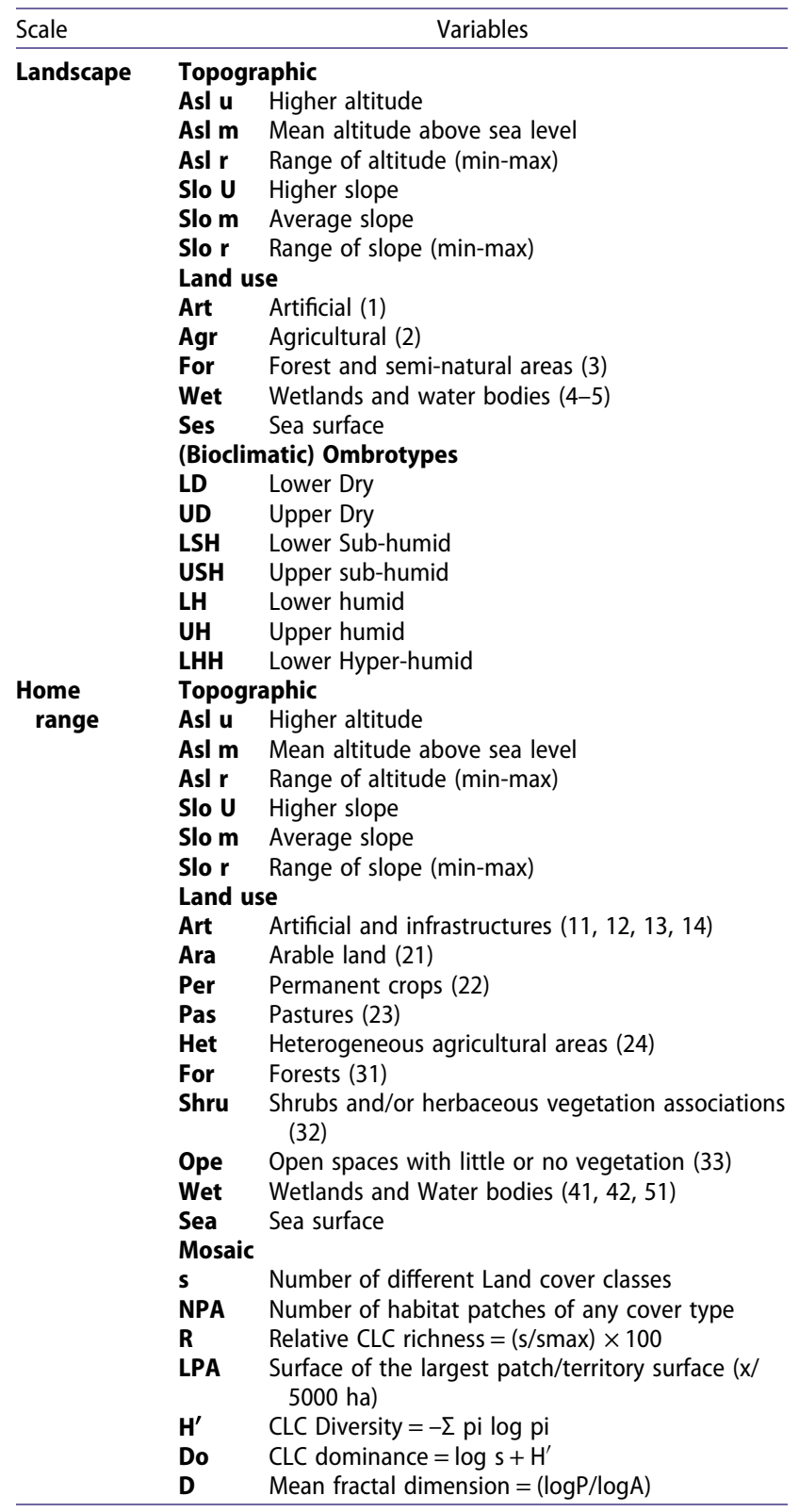

tests, which, unlike $P$-values, are not affected by sample size.

We then fitted generalized linear models (GLMs) to model habitat features characterizing breeding sites of Golden Eagles. The dependent binomial variable (presence/absence of the species) was coded as $1 / 0$ and, therefore, a logit-link function and a binomial distribution of error structure were used (McCullagh \& Nelder 1989). Firstly, we ran a stepwise forward regression procedure to test the statistical significance of each variable in turn. This method has already been used to rank habitat preferences of raptors and to 
obtain predictive distribution models for conservation (Hosmer \& Lemeshow 2000, López-López et al. 2006, 2007a, 2007b). In the regression procedure, we used every subset of variables described in Table 1 as independent predictors. Variables were excluded from each subset when they did not correlate significantly with the presence of Golden Eagles (Wald test $P>$ 0.05; Di Vittorio et al. 2012, 2014). We avoided performing a global model including all subsets because the introduction of such a large number of predictors could cause over-parameterization and over-fitting problems (Balbontín 2005, López-López et al. 2007a, Di Vittorio \& López-López 2014). Environmental variables were standardized to eliminate the effect of differences in the original scale of measurement.

To prevent the bias in model parameters estimation due to spatial autocorrelation (Legendre \& Legendre 1998), we corrected the models by including a spatial term using a third-degree polynomial equation of the central latitude $(x)$ and longitude $(y)$ of each cell as follows (Borcard \& Legendre 2002):

$$
\begin{aligned}
& b_{1} x+b_{2} y+b_{3} x^{2}+b_{4} x y+b_{5} y^{2}+b_{6} x^{3}+b_{7} x^{2} y \\
& +b_{8} x y^{2}+b_{9} y^{3}
\end{aligned}
$$

Then, to eliminate the non-significant spatial terms (Legendre \& Legendre 1998), we ran a preliminary stepwise forward regression with the nine terms of the equation as predictor variables and the presence/ absence of Golden Eagles as dependent variables. Subsequently, the significant spatial terms $(P<0.05)$ were included with other variables (i.e. topographic, land use and bioclimatic or mosaic) in each model to test if these accounted for a significant change in deviance. Finally, after running independent logistic regression models corrected for spatial autocorrelation, we built three additional models at each scale including only significant variables obtained in previous analyses by running the best subset regression option. At every subset of each scale, we selected the best model ranked by Akaike's information criterion corrected for small sample sizes (AICc; Akaike 1973, Burnham \& Anderson 2002). To facilitate the interpretation of results, we plotted the predicted probability of each of the best models for each subset of environmental predictor at both scales (landscape and home range). Finally, we also tested the spatial distribution pattern of territories in Sardinia by means of the Moran's test for spatial autocorrelation (Moran 1950). Statistical significance was set in all analyses at $P<0.05$, which were run in $\mathrm{R}$ (R Core Team 2020).

\section{Results}

\section{Landscape scale}

According to univariate tests, all variables except wetlands and water bodies (Wet), Lower- Hyperhumid (LHH) and Upper Dry Ombrotype (UD) showed significant differences between occupied and unoccupied UTM squares (Table 2). The highest effect sizes were observed for forest (For), higher altitude (Asl $\mathrm{u}$ ) and range of altitude (Asl r), illustrating the preference of Golden Eagles for forest habitats at higher elevation above sea level (Table 2).

At the landscape scale, the GLMs results showed that the probability of occurrence of Golden Eagles increased with longitude ((Table 3). Regarding the topographic subset, the occurrence of Golden Eagles was positively correlated with slope (mean and range) and with the highest elevation above sea level, and negatively correlated with mean elevation (Table 3 ). In terms of land use, the probability of eagle occupation increased with the increase in forested areas. Regarding the bioclimatic subset, the distribution of Golden Eagles in Sardinia was significantly correlated with territories characterized by a moderate degree of humidity, in particular with the sub-humid ombrothermic profiles typical of the mountainous and elevated areas of the region (Canu et al. 2015). The relationship between the predicted probability of occurrence of the species and each set of environmental predictors showed a combination of linear and non-linear shapes, evidencing complex relationships between the presence of eagles and environmental characteristics (Figure 2).

\section{Home range scale}

Moran's test for spatial autocorrelation showed that the distribution pattern of Golden Eagle territories in Sardinia was significantly clustered (Moran's Index = $0.35, z$-score $=12.78, P=0.01$ ). At this scale, univariate tests comparing occupied territories and circular plots used as control showed significant differences in topographic variables, land use variables except for infrastructures (Art), permanent crops (Per), heterogeneous agricultural areas (Het), and wetlands (Wet), and all mosaic predictors (Table 4). The effect size was high for topographic predictors, moderate for forests (For), shrublands (Shru) and open spaces with little or no vegetation (Ope). The highest negative effect size was observed for arable farmland (Ara) (Table 4).

The GLMs results showed a complex effect of longitude on the distribution of the Golden Eagle at 
Table 2. Comparisons of environmental predictor values (mean and standard deviation) in cells occupied (presence) and unoccupied (absence) by the Golden Eagle in Sardinia. Land use surface expressed in hectares. See variables abbreviations in Table 1. Abbreviations: $\mathrm{BH}=$ Benjamini \& Hochberg method (1995).

\begin{tabular}{|c|c|c|c|c|c|c|c|c|c|c|c|}
\hline \multirow[b]{2}{*}{ Group } & \multirow[b]{2}{*}{ Variable } & \multicolumn{2}{|c|}{ Occupied } & \multicolumn{2}{|c|}{ Unoccupied } & \multirow[b]{2}{*}{ W } & \multirow[b]{2}{*}{$P$} & \multicolumn{3}{|c|}{ Effect size } & \multirow[b]{2}{*}{ P-corrected $\mathrm{BH}$} \\
\hline & & Mean & sd & Mean & sd & & & $r$ & Lower $95 \% \mathrm{Cl}$ & Upper $95 \% \mathrm{Cl}$ & \\
\hline \multirow[t]{6}{*}{ Topographic } & Asl u & 849.42 & 297.09 & 469.87 & 329.80 & 4502 & 0.000 & 0.508 & 0.424 & 0.584 & 0.000 \\
\hline & Asl m & 398.33 & 240.05 & 205.42 & 212.29 & 5448 & 0.000 & 0.438 & 0.349 & 0.524 & 0.000 \\
\hline & Asl $r$ & 726.92 & 221.33 & 401.81 & 260.69 & 3926 & 0.000 & 0.550 & 0.471 & 0.624 & 0.000 \\
\hline & Slo U & 69.12 & 7.66 & 57.91 & 13.98 & 5410 & 0.000 & 0.441 & 0.347 & 0.522 & 0.000 \\
\hline & Slo $\mathrm{m}$ & 15.26 & 5.68 & 8.83 & 5.80 & 4650 & 0.000 & 0.497 & 0.411 & 0.573 & 0.000 \\
\hline & Slo $r$ & 69.12 & 7.66 & 57.89 & 13.97 & 5393 & 0.000 & 0.442 & 0.356 & 0.523 & 0.000 \\
\hline \multirow[t]{5}{*}{ Land use } & Art & 175.75 & 281.03 & 268.81 & 439.25 & 13832 & 0.001 & -0.180 & -0.284 & -0.072 & 0.002 \\
\hline & Agr & 2883.50 & 2367.34 & 4021.17 & 3156.27 & 13471 & 0.007 & -0.154 & -0.261 & -0.051 & 0.009 \\
\hline & For & 5915.98 & 2736.45 & 2550.06 & 2303.79 & 4059 & 0.000 & 0.540 & 0.456 & 0.618 & 0.000 \\
\hline & Wet & 45.99 & 140.18 & 122.03 & 374.64 & 12441 & 0.103 & -0.092 & -0.198 & 0.019 & 0.109 \\
\hline & Ses & 978.77 & 2420.77 & 3037.93 & 3929.49 & 14793 & 0.000 & -0.285 & -0.382 & -0.194 & 0.000 \\
\hline \multirow[t]{7}{*}{ Bioclimatic } & LD & 362.01 & 924.00 & 1333.45 & 2647.99 & 13498 & 0.003 & -0.169 & -0.274 & -0.063 & 0.004 \\
\hline & UD & 3193.52 & 2658.71 & 3304.64 & 3185.32 & 11303 & 0.914 & 0.006 & -0.095 & 0.119 & 0.914 \\
\hline & LSH & 3411.20 & 2538.48 & 1626.85 & 2452.48 & 5797 & 0.000 & 0.416 & 0.321 & 0.502 & 0.000 \\
\hline & USH & 1332.10 & 1820.69 & 597.32 & 1544.54 & 6125 & 0.000 & 0.420 & 0.319 & 0.524 & 0.000 \\
\hline & $\mathrm{LH}$ & 683.99 & 1742.59 & 113.49 & 594.33 & 8006 & 0.000 & 0.339 & 0.221 & 0.448 & 0.000 \\
\hline & $\mathrm{UH}$ & 46.13 & 311.38 & 0.54 & 7.05 & 10826 & 0.012 & 0.142 & 0.023 & 0.238 & 0.014 \\
\hline & $\mathrm{LHH}$ & 1.94 & 19.29 & 0.00 & 0.00 & 11194 & 0.071 & 0.103 & 0.067 & 0.168 & 0.079 \\
\hline
\end{tabular}

the home range scale, with the probability of occurrence increasing moderately from west to east (Table 5). Moreover, the probability of a territory being occupied increased with increasing altitude above sea level and slope, and was negatively correlated with arable land extension (poorly represented in the areas occupied by the species and distributed in non-suitable areas) and with the proximity to the coastline (Table 5). Finally, the distribution of the Golden Eagle was negatively correlated with the fractal dimension which measures the degree of shape complexity, which is a good proxy of habitat fragmentation (Rutledge 2003). Similar to the landscape level, the relationship between the predicted probability of occurrence of the species and each set of environmental predictors showed a mixture of combinations of linear and non-linear shapes (Figure 3).

\section{Discussion}

The island of Sardinia is a suitable area for Golden Eagles, based on its landscape characteristics, low human density (68 inhabitants per $\mathrm{km}^{2}$, https://ugeo. urbistat.com) and landscape characteristics that favour relatively abundant prey availability. Indeed, with at least 56 pairs in 2020, this island hosts an important

Table 3. Generalized linear model (GLM) estimates and significance statistics of the Wald test for the probability of occurrence of Golden Eagles in Sardinia at landscape scale. Variable abbreviations available in Table 1. Abbreviations: AICc = Akaike Information Criterion corrected for small sample size; $\mathrm{df}=$ degrees of freedom; $L R=$ likelihood ratio test.

\begin{tabular}{|c|c|c|c|c|c|c|c|c|}
\hline Variable & Estimate & Standard & Wald & $P$ & $\mathrm{AICC}$ & df & $\operatorname{LR} X^{2}$ & $P$ \\
\hline \multicolumn{9}{|l|}{ Spatial } \\
\hline Intercept & -0.523 & 0.121 & 18.624 & 0.000 & & & & \\
\hline$x$ & 0.510 & 0.125 & 16.747 & 0.000 & & & & \\
\hline Explained deviance \% & 94.40 & & & & & & & \\
\hline \multicolumn{9}{|l|}{ Topographic } \\
\hline Intercept & -0.838 & 0.163 & 26.545 & 0.000 & 296.448 & 4 & 126.554 & 0.000 \\
\hline Asl u & 1.656 & 0.397 & 17.418 & 0.000 & & & & \\
\hline Asl $\mathrm{m}$ & -0.705 & 0.348 & 4.113 & 0.043 & & & & \\
\hline Slo r & 0.658 & 0.272 & 5.847 & 0.016 & & & & \\
\hline Slo $\mathrm{m}$ & 0.535 & 0.196 & 7.437 & 0.006 & & & & \\
\hline Explained deviance \% & 67.00 & & & & & & & \\
\hline \multicolumn{9}{|l|}{ Land use } \\
\hline Intercept & -0.633 & 0.143 & 19.701 & 0.000 & & & & \\
\hline For & 1.390 & 0.164 & 72.228 & 0.000 & & & & \\
\hline Explained deviance \% & 67.00 & & & & & & & \\
\hline \multicolumn{9}{|l|}{ Bioclimatic } \\
\hline Intercept & -0.570 & 0.135 & 17.944 & 0.000 & 395.358 & 3 & 25.592 & 0.000 \\
\hline UD & 0.316 & 0.141 & 5.002 & 0.025 & & & & \\
\hline LSH & 0.850 & 0.137 & 38.255 & 0.000 & & & & \\
\hline $\mathrm{LH}$ & 0.811 & 0.203 & 16.003 & 0.000 & & & & \\
\hline Explained deviance \% & 81.14 & & & & & & & \\
\hline
\end{tabular}


population of this raptor (about $9 \%$ of the Italian population; Fasce \& Fasce 2017, Ruiu 2017).

Our results showed that topographic, land use and bioclimatic factors could properly describe the habitat preferences of Golden Eagles in Sardinia. At both scales, our models showed a positive effect of longitude on the probability of occurrence of the species. This result can be explained by the distribution of the main mountain ranges in the island, which follow a positive west-east gradient.

In relation to topographic factors, the occurrence of Golden Eagles was correlated with more rugged areas, highlighting that the species selects cells with pronounced slope. The slope-linked variables were correlated with Golden Eagle occurrence at both scales, as already reported in other studies (Carrete et al. 2000, McIntyre et al. 2006, Tapia et al. 2007, Sergio et al. 2006, Katzner et al. 2012a, Di Vittorio \& López-López 2014, Stefânescu \& Bâlescu 2019, Fielding et al. 2020). The results regarding elevation support this idea, suggesting that the species prefers areas with single high-elevation places (positive correlation with higher elevation) above a lowerelevation background (negative correlation with mean elevation). The species seems to prefer territories characterized by a rugged topography that provides suitable places for nesting. As cliff availability is correlated to the ruggedness of the terrain (Carrete et al. 2000, Balbontín 2005, López-López et al. 2006), it is likely that the observed preference for rugged land is merely reflecting the availability of suitable nesting cliffs (López-López et al. 2004, 2007a).

Topography is also known to influence the flight behaviour of eagles, with the efficiency of movements across the territory being favoured by thermals and orographic uplifts (Bohrer et al. 2012, Katzner et al. 2012b, Singh et al. 2016, Fielding et al. 2020) that may facilitate displacement and eventually foraging (McGrady et al. 2002, McLeod et al. 2002). Since the wing morphology of Golden Eagles is adapted for soaring flight (McGrady 1997, Watson 1997), landscape features that support soaring flight may be preferred (Fielding et al. 2020). In addition, a rugged topography may imply a higher availability of three-

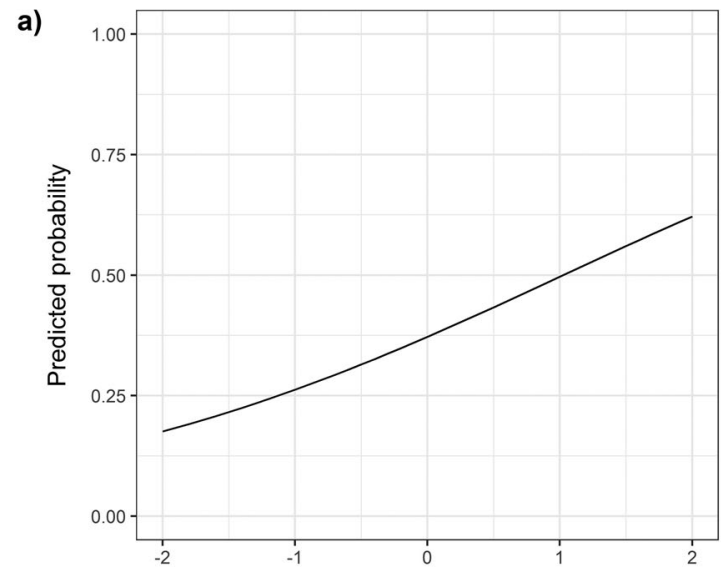

c)

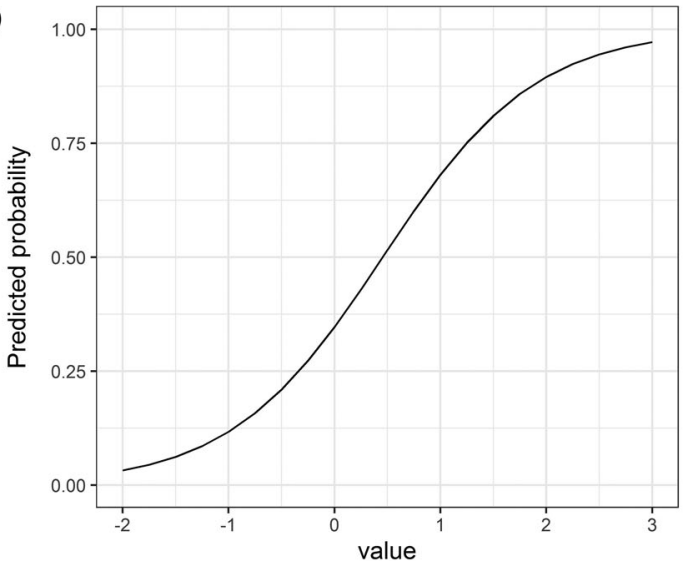

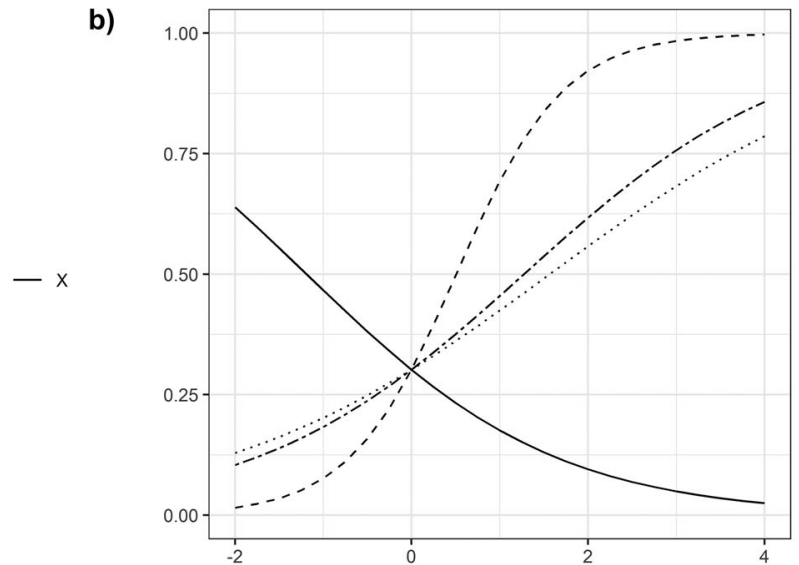

- Asl $m$

- - Aslu

… Slo $\mathrm{m}$

-.- Slor

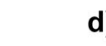

d)

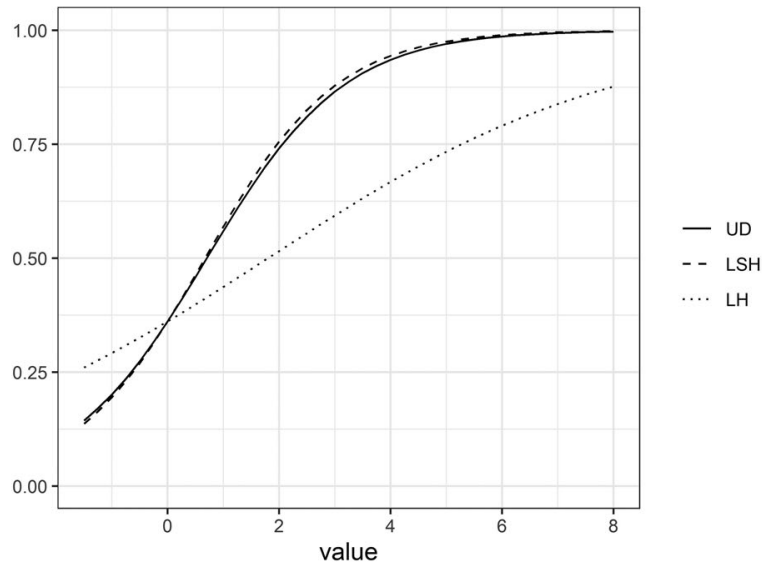

Figure 2. Predicted probability of occurrence of Golden Eagle in Sardinia according to the best GLM model for (a) spatial, (b) topographic, (c) land use, and (d) bioclimatic environmental predictors at landscape scale. See Table 1 for abbreviations of explanatory variables. Value in $x$-axis refers to standardized values of each independent predictor included in the best GLM. 
Table 4. Comparisons of environmental predictors (mean and standard deviation) in occupied territories and a random set of unoccupied $5 \mathrm{~km}$-radius plots by the Golden Eagle in Sardinia. Land use surface expressed in hectares. See variables abbreviations in Table 1. Abbreviations: BH = Benjamini \& Hochberg method (1995).

\begin{tabular}{|c|c|c|c|c|c|c|c|c|c|c|c|}
\hline \multirow[b]{2}{*}{ Group } & \multirow[b]{2}{*}{ Variable } & \multicolumn{2}{|c|}{ Territories } & \multicolumn{2}{|c|}{ Control } & \multirow[b]{2}{*}{ W } & \multirow[b]{2}{*}{$P$} & \multicolumn{3}{|c|}{ Effect size } & \multirow[b]{2}{*}{ P-corrected $\mathrm{BH}$} \\
\hline & & Mean & sd & Mean & sd & & & $r$ & Lower $95 \% \mathrm{Cl}$ & Upper 95\% Cl & \\
\hline \multirow[t]{6}{*}{ Topographic } & Asl u & 917.66 & 279.36 & 517.48 & 237.22 & 424 & 0.000 & 0.629 & 0.503 & 0.716 & 0.000 \\
\hline & Asl $\mathrm{m}$ & 498.00 & 227.04 & 232.93 & 180.94 & 523 & 0.000 & 0.575 & 0.437 & 0.700 & 0.000 \\
\hline & Asl $r$ & 756.19 & 197.31 & 436.77 & 183.21 & 346 & 0.000 & 0.672 & 0.562 & 0.759 & 0.000 \\
\hline & Slo U & 69.66 & 7.33 & 58.59 & 10.02 & 533 & 0.000 & 0.569 & 0.436 & 0.690 & 0.000 \\
\hline & Slo $\mathrm{m}$ & 17.32 & 4.69 & 8.35 & 4.01 & 209 & 0.000 & 0.747 & 0.661 & 0.812 & 0.000 \\
\hline & Slo $r$ & 69.66 & 7.33 & 58.59 & 10.02 & 533 & 0.000 & 0.569 & 0.434 & 0.682 & 0.000 \\
\hline \multirow[t]{10}{*}{ Land use } & Art & 303.68 & 441.43 & 307.43 & 521.11 & 1722 & 0.371 & -0.085 & -0.276 & 0.101 & 0.473 \\
\hline & Ara & 98.11 & 266.57 & 2260.06 & 1709.94 & 2999 & 0.000 & -0.810 & -0.866 & -0.733 & 0.000 \\
\hline & Per & 208.03 & 443.92 & 291.83 & 599.89 & 1743 & 0.279 & -0.103 & -0.285 & 0.079 & 0.401 \\
\hline & Pas & 4.59 & 24.69 & 81.86 & 174.61 & 2059 & 0.000 & -0.383 & -0.516 & -0.252 & 0.000 \\
\hline & Het & 2146.48 & 1633.33 & 1667.99 & 1096.02 & 1324 & 0.156 & 0.134 & -0.062 & 0.327 & 0.239 \\
\hline & For & 1467.86 & 1351.82 & 787.61 & 962.10 & 977 & 0.001 & 0.325 & 0.159 & 0.485 & 0.001 \\
\hline & Shru & 3053.62 & 1619.19 & 1761.13 & 1247.06 & 858 & 0.000 & 0.390 & 0.215 & 0.534 & 0.000 \\
\hline & Ope & 252.89 & 364.06 & 80.74 & 189.16 & 952 & 0.000 & 0.352 & 0.177 & 0.512 & 0.000 \\
\hline & Wet & 202.57 & 955.39 & 91.11 & 327.40 & 1461 & 0.424 & 0.076 & -0.128 & 0.265 & 0.514 \\
\hline & Sea & 113.75 & 556.03 & 524.00 & 1451.22 & 1793 & 0.023 & -0.214 & -0.355 & -0.049 & 0.045 \\
\hline \multirow[t]{7}{*}{ Mosaic } & $S$ & 9.64 & 2.33 & 10.39 & 2.44 & 1855 & 0.092 & -0.160 & -0.327 & 0.029 & 0.152 \\
\hline & NPA & 35.20 & 12.44 & 37.27 & 12.78 & 1688 & 0.487 & -0.066 & -0.251 & 0.122 & 0.560 \\
\hline & $\mathrm{R}$ & 25.38 & 6.13 & 27.35 & 6.42 & 1855 & 0.092 & -0.160 & -0.332 & 0.011 & 0.152 \\
\hline & LPA & 0.46 & 0.16 & 0.46 & 0.15 & 1609 & 0.814 & -0.023 & -0.211 & 0.170 & 0.851 \\
\hline & $\mathrm{H}^{\prime}$ & 1.54 & 0.38 & 1.55 & 0.33 & 1554 & 0.935 & 0.008 & -0.175 & 0.199 & 0.935 \\
\hline & Do & 2.50 & 0.50 & 2.55 & 0.43 & 1616 & 0.782 & -0.026 & -0.202 & 0.155 & 0.851 \\
\hline & $D$ & 0.70 & 0.01 & 0.70 & 0.01 & 1735 & 0.333 & -0.092 & -0.293 & 0.116 & 0.450 \\
\hline
\end{tabular}

dimensional space per unit of two-dimensional space. This favours the potential for undetected approach to prey (Watson 1991). Finally, in mountainous regions, more rugged territories often have lower levels of human disturbance, which in turn favours the presence of eagles (Watson 1997).

At the landscape scale, the occurrence of Golden Eagles increased with the surface area occupied by the forest. These areas are particularly widespread in the mountainous regions of Sardinia (Camarda et al.
2015) and have increased in recent decades as a result of land abandonment by farmers since the 1960s (Ruiu 2017). Although this preference for forest has already been reported in some studies (Tjernberg 1983, Bergo 1984, Watson 1992, Chaparro 1996, Watson 1997, Carrete et al. 2000, López-López et al. 2007a, Stefânescu \& Bâlescu 2019), other studies analysing the relationship between Golden Eagle distribution and forest area revealed that the species prefers open habitats and usually avoids woodlands

Table 5. Generalized linear model (GLM) estimates and significance statistics of the Wald test of the probability of occurrence of Golden Eagle in Sardinia at home range scale. Abbreviations: AIC = Akaike Information Criterion corrected for small sample size; $\mathrm{df}=$ degrees of freedom; $\mathrm{LR}=$ likelihood ratio test.

\begin{tabular}{|c|c|c|c|c|c|c|c|c|}
\hline Variable & Estimate & Standard & Wald & $P$ & AICc & $\mathrm{df}$ & $\mathrm{LR}^{2}{ }^{2}$ & $P$ \\
\hline \multicolumn{9}{|l|}{ Spatial } \\
\hline Intercept & -0.002 & 0.191 & 0.000 & 0.990 & & & & \\
\hline$x^{3}$ & 0.693 & 0.201 & 11.849 & 0.001 & & & & \\
\hline \multicolumn{8}{|l|}{ Topographic } & \\
\hline Intercept & -0.273 & 0.344 & 0.631 & 0.427 & 74.314 & 3 & 103.036 & 0.000 \\
\hline Asl m & 0.968 & 0.461 & 4.403 & 0.036 & & & & \\
\hline Slo U & 1.435 & 0.615 & 5.448 & 0.020 & & & & \\
\hline Slo $\mathrm{m}$ & 2.527 & 0.616 & 16.832 & 0.000 & & & & \\
\hline Explained deviance \% & 43.22 & & & & & & & \\
\hline \multicolumn{9}{|l|}{ Land use } \\
\hline Intercept & -2.344 & 0.855 & 7.515 & 0.006 & 68.964 & 2 & 106.274 & 0.000 \\
\hline Ara & -6.113 & 1.493 & 16.773 & 0.000 & & & & \\
\hline Sea & -0.854 & 0.305 & 7.835 & 0.005 & & & & \\
\hline Explained deviance \% & 44.66 & & & & & & & \\
\hline \multicolumn{9}{|l|}{ Mosaic } \\
\hline Intercept & -0.004 & 0.197 & 0.000 & 0.985 & 155.516 & 2 & 19.612 & 0.000 \\
\hline$x^{3}$ & 0.826 & 0.216 & 14.552 & 0.000 & & & & \\
\hline$D$ & -0.515 & 0.210 & 6.007 & 0.014 & & & & \\
\hline Explained deviance \% & 84.86 & & & & & & & \\
\hline
\end{tabular}


for hunting (Watson et al. 1987, McGrady et al. 1997, Pedrini \& Sergio 2001, McGrady et al. 2002, Balbontín 2005, Ontiveros et al. 2005, Di Vittorio \& LópezLópez 2014, Watson 2010, Katzner et al. 2012a). Furthermore, forest cover could negatively influence the breeding success (Whitfield et al. 2001, 2007). However, the natural and semi-natural woodland structure of Sardinia is often full of open landscapes with widely spaced trees, facilitating prey capture by large raptors like the Golden Eagle (Watson 1992).

Our results showed that Golden Eagles tend to occupy areas characterized by relatively high levels of humidity, most likely to avoid excessive temperatures during the breeding season (Steenhof et al. 1997, López-López et al. 2007a), and confirming that the occurrence of the species can be influenced by climatic factors (Beecham \& Kochert 1975, Watson et al. 2003, López-López et al. 2007a, Moreno-Rueda et al. 2009, McIntyre \& Schmidt 2012, Di Vittorio \& López-López 2014, Stefânescu \& Bâlescu 2019).

At the home range scale, the area of arable farmland was negatively correlated with the presence of Golden
Eagles. This avoidance of arable farmland, also reported in other studies (Marzluff et al. 1997, Watson 2010, Carrete et al. 2000, López-López et al. 2007a, Katzner et al. 2012a, Stefânescu \& Bâlescu 2019), could be explained by different, non-mutually exclusive reasons: (i) the disturbance caused by a high number of people working on agricultural land (Carrete et al. 2000), (ii) the fact that this land use class is not very common within the altitude occupied by the species in Sardinia; or (iii) its poor preyproductivity due to the type of management (Stefânescu \& Bâlescu 2019). However, in general, the relationship between Golden Eagles and agricultural areas should not be considered as necessarily negative, as shown by the traditional management of small agricultural areas in Spain (Tapia et al. 2007) or Sicily (Di Vittorio \& López-López 2014), where the occurrence of Golden Eagles at the territory scale was positively related with the area of arable farmland.

At both spatial scales, we found a clear negative effect of sea surface extent (a good proxy of coastal environment). This is probably due to an interactive a)

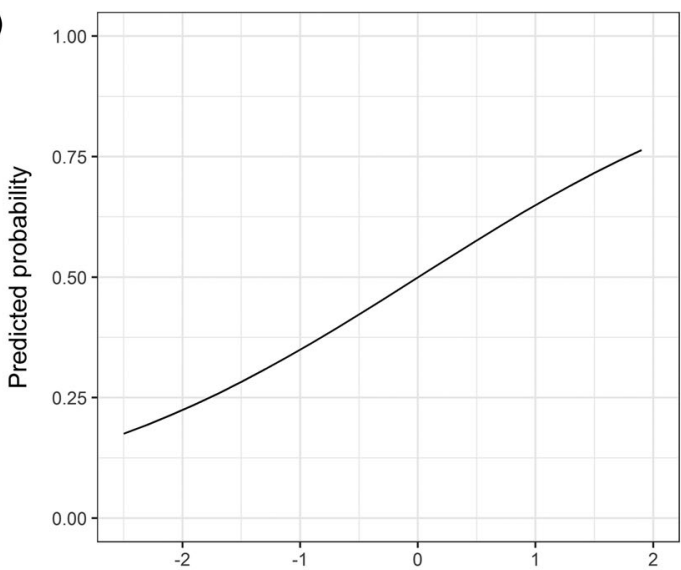

c)

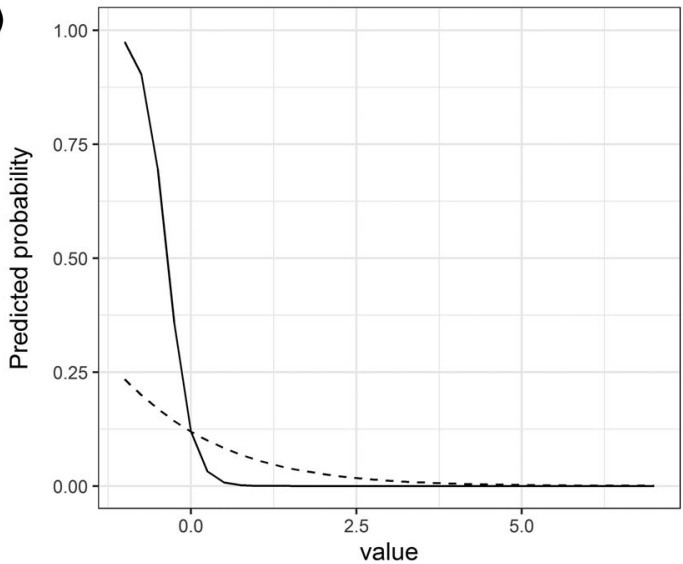

b)

$-x^{3}$

- Ara

- - Sea b)

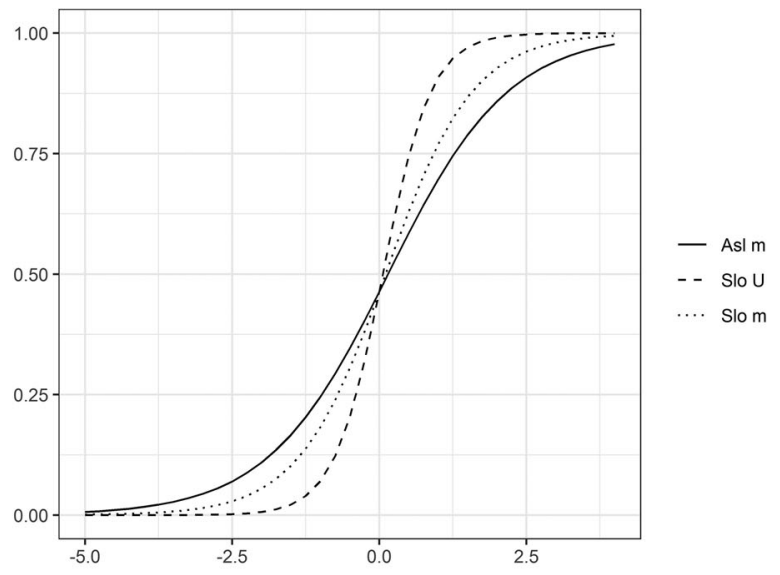

d)

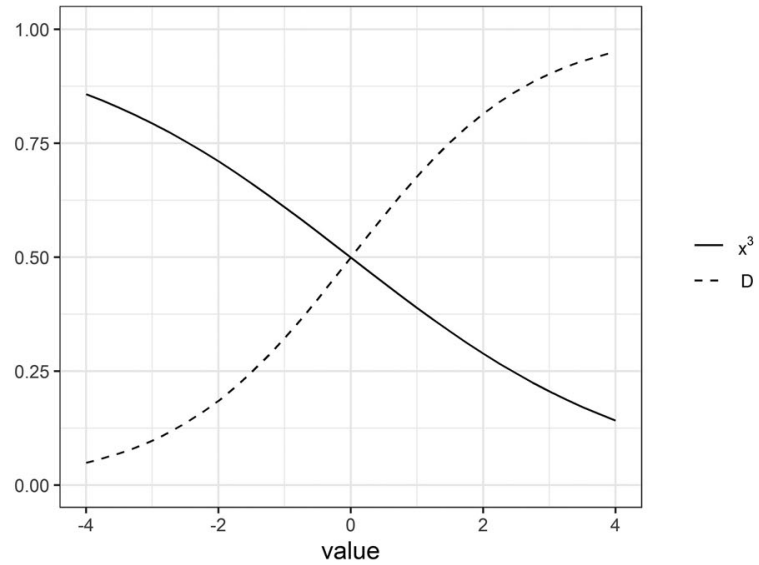

Figure 3. Predicted probability of occurrence of Golden Eagle in Sardinia according to the best GLM model for (a) spatial, (b) topographic, (c) land use, and (d) mosaic environmental predictors at home range scale. See Table 1 for abbreviations of explanatory variables. Value in $x$-axis refers to standardized values of each independent predictor included in the best GLM. 
effect between higher human presence and less suitable habitat of these areas (López-López et al. 2007a). As other studies suggest, Golden Eagles could avoid coastal places with strong human presence for nesting because of their potential 'low quality' for breeding (Carrete et al. 2002, Whitfield et al. 2004, López-López et al. 2007a), as this raptor is rather intolerant of persistent human presence (Watson \& Dennis 1992, Watson 1997, Brendel et al. 2002, McLeod et al. 2002, López-López et al. 2004, Kaisanlahti-Jokimäki et al. 2008, Martin et al. 2009, Watson 2010, Lado \& Tapia 2012). Furthermore, marine habitats provide fewer updrafts and potentially poor prey densities for the species (Watson 1997).

Finally, the negative association of the species distribution with environmental complexity (as explained by the variable 'mean fractal dimension') could indicate the preference of Golden Eagles for large portions of continuous suitable habitat and, therefore, the threat produced by habitat fragmentation and shrinkage of suitable habitat patches (Watson 2010, Katzner et al. 2012a, D'Addario et al. 2019). This is particularly important in Sardinia, where very frequent summer arson (Nudda et al. 2015) and land abandonment can favour habitat fragmentation in many otherwise suitable areas of the island (PAF 2014).

\section{Conservation implications}

The results of this study could contribute to future management strategies and conservation projects aimed at protecting Golden Eagles in Sardinia, and may be used to identify the most suitable conservation areas for this raptor. In order to maintain suitable areas for this population, we recommend that management should be focused on maintaining open and forested habitats, especially within the altitudinal range occupied by the species.

Finally, there is another implication with regards to potential competition with the Bonelli's Eagle, for which a reintroduction project is underway in Sardinia. Topographic, land use and bioclimatic factors are among the main factors determining the segregation between these two species (Gil-Sánchez et al. 1994, López-López et al. 2004, Román-Muňoz et al. 2005, Carrascal \& Seoane 2009, Moreno-Rueda et al. 2009). Our results support the idea of partial niche segregation between the species, as areas occupied by Golden Eagle are usually higher in altitude and colder than those occupied by Bonelli's Eagle (Gil-Sánchez et al. 1994, López-López et al. 2004, Moreno-Rueda et al. 2009). Moreover, Bonelli's
Eagle seems to be more tolerant to human presence than Golden Eagle (López-López et al. 2004, MorenoRueda et al. 2009), and the extensive non-irrigated agricultural areas are fundamental components of the landscapes favoured by Bonelli's Eagle (Ontiveros \& Pleguezuelos 2003, Penteriani et al. 2003, Gil-Sánchez et al. 2004, López-López et al. 2007a, Carrascal \& Seoane 2009, López-López \& Urios 2010, Di Vittorio et al. 2012), especially if associated with high habitat complexity (López-López et al. 2011, Di Vittorio et al. 2012). Thus, our results highlight different patterns of habitat selection and niche segregation regarding land use, bioclimatic conditions and human pressure that should favour the coexistence of Golden and Bonelli's Eagles in Sardinia, giving hope for the success (at least in relation to the competition factor) of the ongoing reintroduction project for the Bonelli's Eagle.

\section{Acknowledgments}

We thank Fo.Re.S.T.A.S. (Agenzia Forestale Regionale per lo Sviluppo del Territorio e dell'Ambiente della Sardegna) and the Corpo Forestale e Vigilanza Ambientale for their contribution for this research. Two anonymous reviewers and the Associate Editor made valuable suggestions that improved this manuscript.

\section{ORCID}

M. Di Vittorio (D) http://orcid.org/0000-0001-7733-1551

M. Grussu (D) http://orcid.org/0000-0001-5173-6948

P. López-López (iD http://orcid.org/0000-0001-5269-652X

\section{References}

Akaike, H. 1973. Information theory and an extension of the maximum likelihood principle. In Petrov, B.N. \& Csaki. F. (eds) Second International Symposium on Information Theory, 267-281. Akademia Kiado, Budapest, Hungary.

Asuni, V., Fadda, A. \& Medda, M. 2003. Deposizioni precoci dell'Aquila reale Aquila chrysaetos in Sardegna. Aves Ichnusae 6: 3-11.

Balbontín, J. 2005. Identifying suitable habitat for dispersal in Bonelli's Eagle: an important issue in halting its decline in Europe. Biol. Conserv. 126: 74-83.

Beecham, J.J. \& Kochert, M.N. 1975. Breeding biology of Golden Eagle in Southwestern Idaho. Wilson Bull. 87: 506-513.

Benjamini, Y. \& Hochberg, Y. 1995. Controlling the false discovery rate: a practical and powerful approach to multiple testing. J. R. Stat. Soc. B 57: 289-300.

Bergo, G. 1984. Habitat and nest-site features of Golden Eagle Aquila chrysaetos (L.) in Hordaland, West Norway. Fauna Norv. Ser. C., Cinclus 7: 109-113.

BirdLife International. 2017. Species factsheet: Aquila chrysaetos. http://www.birdlife.org. 
Bohrer, G., Brandes, D. \& Mandel, J.T. 2012. Estimating updraft velocity components over large spatial scales: contrasting migration strategies of Golden Eagles and Turkey Vultures. Ecol. Lett. 15: 96-103.

Borcard, D. \& Legendre, P. 2002. All-scale spatial analysis of ecological data by means of principal coordinates of neighbour matrices. Ecol. Model. 153: 51-68.

Brendel, U., Eberhardt, R. \& Wiesmann, K. 2002. Conservation of the Golden Eagle (Aquila chrysaetos) in the European Alps; a combination of education, cooperation, and modern techniques. J. Raptor Res. 36: 20-24.

Brichetti, P. \& Fracasso, G. 2003. Ornitologia italiana Gavidae-Falconidae Alberto Perdisa Editore, Bologna.

Burnham, K.P. \& Anderson, D.R. 2002. Model Selection and Multimodel Inference: a practical information-theoretic approach, 2nd edn. Springer, New York.

Camarda, I., Laureti, L. \& Angelini, P. 2015. Il Sistema Carta della Natura della Sardegna. ISPRA, Serie Rapporti, 222/ 2015.

Canu, S., Rosati, L. \& Fiori, M. 2015. Bioclimate map of Sardinia (Italy). J. Maps 11: 711-718.

Carrascal, L.M. \& Seoane, J. 2009. Factors affecting largescale distribution of the Bonelli's Eagle Aquila fasciata in Spain. Ecol. Res. 24: 565-573.

Carrete, M., Sànchez-Zapata, J.A. \& Calvo, J.F. 2000. Breeding densities and habitat attributes of Golden Eagles in south-eastern Spain. J. Raptor Res. 34: 48-52.

Carrete, M., Sánchez-Zapata, J.A. \& Calvo, J.F. 2005. Demography and habitat availability in territorial occupancy of two competing species. Oikos 108: 125-136.

Carrete, M., Sánchez-Zapata, J.A. \& Martínez, J.E. 2001. Distribución espacial del Águila Azor Perdicera (Hieraaetus fasciatus) y del Águila Real (Aquila chrysaetos) en la Región de Murcia. Ardeola 48: 175-182.

Carrete, M., Sánchez-Zapata, J.A. \& Martínez, J.E. 2002. Factors influencing the decline of a Bonelli's Eagle Hieraaetus fasciatus population in southeastern Spain: demography, habitat or competition? Biodiv. Conserv. 11: 975-985.

Chaparro, J. 1996. Distribución potencial del bosque y de sus especies arbóreas en zonas mediterráneas semi-áridas: modelos y aplicaciones. PhD Dissertation, Universidad de Murcia, Murcia, Spain.

D’Addario, M., Monroy-vilchis, O. \& Zarco-González, M.M. 2019. Potential distribution of Aquila chrysaetos in Mexico: implications for conservation. Avian Biol. Res. 12: $33-41$.

Del Hoyo, J., Elliott, A. \& Sargatal, J. 1994. Handbook of the Birds of the World, Vol. 2, New World Vultures to Guineafowl. Lynx Edicions, Barcelona, Spain.

Di Vittorio, M., López-López, P. \& Sarà, M. 2012. Habitat preference of Bonelli's Eagle (Aquila fasciata) in Sicily. Bird Study 59: 207-217.

Di Vittorio, M. \& López-López, P. 2014. Spatial distribution and breeding performance of Golden Eagles Aquila chrysaetos in Sicily: implications for conservation. Acta Orn. 49: 33-45

EEA. 2000. Corine Land Cover Technical guide Addendum 2000. http://www.eea.europa.eu/publications/tech40add, accessed 08.11.2013.

Fasce, P. \& Fasce, L. 2003. L'Aquila reale Aquila chrysaetos in Italia: un aggiornamento sullo status della popolazione. Avocetta 27: 10 .
Fasce, P., Fasce, L. 2017. A comment about the meeting's results. Avocetta 41: 93-95.

Ferguson-Lees, J. \& Christie, D.A. 2001. Raptors of the World. Christopher Helm, London, UK.

Fielding, A.H., Haworth, P.F. \& Anderson, D. 2020. A simple topographical model to predict Golden Eagle Aquila chrysaetos space use during dispersal. Ibis 162: 400-415.

Forman, R.T.T. 1995. Land Mosaics: The Ecology of Landscapes and Regions. Cambridge University Press, Cambridge.

Gil-Sánchez, J.M., Moleón, M., Otero, M. \& Bautista, J. 2004. A nine-year study of successful breeding in a Bonelli's eagle population in southeast Spain: a basis for conservation. Biol. Conserv. 118: 685-694.

Gil-Sánchez, J.M., Molino, F.M. \& Valenzuela, G. 1994. Parámetros reproductivos y alimentación del Águila real Aquila chrysaetos y del Águila perdicera Hieraaetus fasciatus en la provincia de Granada. Aegypius 12: 47-51.

Gil-Sánchez, J.M., Molino, F.M. \& Valenzuela, G. 1996. Selección de hábitat de nidificación por el águila perdicera (Hieraaetus fasciatus) en Granada (SE de España). Ardeola 43: 189-197.

Guisan, A. \& Zimmermann, N. 2000. Predictive habitat distribution models in ecology. Ecol. Model. 135: 147-186.

Haworth, P.F., Mcgrady, M.J., Whitfield, D.P., Fielding, A.H. \& McLeod, D.R.A. 2010. Ranging distance of resident Golden Eagles Aquila chrysaetos in western Scotland according to season and breeding status. Bird Study 53: 265-273.

Hosmer, D.W. \& Lemeshow, S. 2000. Applied Logistic Regression Analysis, 2nd edn. Wiley \& Sons, New York.

Kaisanlahti-Jokimäki, M.L., Jokimäki, J. \& Huhta, E. 2008. Territory occupancy and breeding success of the Golden Eagle (Aquila chrysaetos) around tourist destinations in Finland. Orn. Fenn. 85: 2-12.

Katzner, T.E., Smith, B.W. \& Miller, T.A. 2012a. Status, biology, and conservation priorities for North America's eastern Golden Eagle (Aquila chrysaetos) population. Auk 129: $168-176$.

Katzner, T.E., Brandes, D. \& Miller, T. 2012b. Topography drives migratory flight altitude of Golden Eagles: implications for on-shore wind energy development. J. App. Ecol. 49: 1178-1186.

Keating, K.A. \& Cherry, S. 2004. Use and interpretation of logistic regression in habitat selection studies. J. Wildl. Manage. 68: 774-789.

Lado, L.R. \& Tapia, L. 2012. Suitable breeding habitat for Golden Eagle (Aquila chrysaëtos) in a border of distribution area in northwestern Spain: advantages of using remote sensing information vs land use maps. Vie Milieu 62: 77-85.

Larson, M.A., Thompson, F.R. III \& Millspaugh, J.J. 2004. Linking population viability, habitat suitability, and landscape simulation models for conservation planning. Ecol. Model. 180: 103-118.

Legendre, P. \& Legendre, L. 1998. Numerical Ecology. Elsevier Science, Amsterdam, Netherlands.

López-López, P., García-Ripollés, C. \& García-López, F. 2004. Patrón de distribución del águila real Aquila chrysaetos y del águila-azor perdicera Hieraaetus fasciatus en la provincia de Castellón. Ardeola 51: 275-283. 
López-López, P., García-Ripollés, C. \& Aguilar, J.M. 2006. Modelling breeding habitat preferences of Bonelli s eagle (Hieraaetus fasciatus) in relation to topography, disturbance, climate and land use at different spatial scales. J. Ornithol. 147: 97-107.

López-López, P., García-Ripollés, C. \& Soutullo, A. 2007a. Identifying potentially nesting habitat for Golden Eagles (Aquila chrysaetos) applied to Important Bird Areas design. Anim. Conserv. 10: 208-218.

López-López, P., García-Ripollés, C. \& Soutullo, A. 2007b. Are important bird areas and special protected areas enough for conservation? The case of Bonelli's Eagle in a Mediterranean area. Biodivers. Conserv. 16: 3755-3780

López-López, P. \& Urios, V. 2010. Use of digital trail cameras to study Bonelli's Eagle's diet during the nestling season. Ital. J. Zool. 77: 289-295.

López-López, P., Maiorano, L. \& Falcucci, A. 2011. Hotspots of species richness, threat and endemism for terrestrial vertebrates in SW Europe. Acta Oecol. 37: 399-412.

Martí, R. \& del Moral, J.C. 2003. Atlas de las aves reproductoras de España. Dirección General de la Conservación de la Naturaleza-Sociedad Española de Ornitología, Madrid.

Martin, J., McIntyre, C.L. \& Hines, J.E. 2009. Dynamic multistate site occupancy models to evaluate hypotheses relevant to conservation of Golden Eagles in Denali National Park, Alaska. Biol. Conserv. 142: 2726-2731.

Martínez, J.A., Calvo, J.F. \& Martínez, J.E. 2007. Breeding performance, age effects and territory occupancy in a Bonelli's Eagle Hieraaetus fasciatus population. Ibis 150: 223-233.

Marzluff, J.M., Knick, S.T. \& Vekasy, M.S. 1997. Spatial use and habitat selection of Golden Eagle in south-western Idaho. Auk 114: 673-686.

Matyukhina, D.S., Miquelle, D.G. \& Murzin, A.A. 2015. Assessing the influence of environmental parameters on Amur Tiger distribution in the Russian Far East using a MaxEnt modeling approach. Achievements in the Life Sciences 8: 95-100.

McCullagh, P. \& Nelder, J.A. 1989. Generalized Linear Models. Chapman and Hall/CRC, London, UK.

McGrady, M.J. 1997. Aquila chrysaetos Golden Eagle. Birds of the Western Palearctic Update 1: 99-114.

McGrady, M.J., Grant, J.R. \& Bainbridge, I.P. 2002. A model of golden eagle (Aquila chrysaetos) ranging behaviour. J. Raptor Res. 36: 62-69.

McGrady, M.J., McLeod, D.M. \& Petty, S.M. 1997. Golden Eagles and forestry. Forestry Commission Research Information Note No. 292. RSPB, London.

McIntyre, C.L. \& Schmidt, J.H. 2012. Ecological and environmental correlates of territory occupancy and breeding performance of migratory Golden Eagles Aquila chrysaetos in interior Alaska. Ibis 154: 124-135.

McIntyre, C.L., Collopy, M.W. \& Kidd, J.G. 2006. Characteristics of the landscape surrounding Golden Eagle nest sites in Denali National Park and Preserve, Alaska. J. Raptor Res. 40: 46-51.

McLeod, D.R.A., Whitfield, D.P. \& Fielding, A.H. 2002. Predicting home range use by Golden Eagles Aquila chrysaetos in western Scotland. Avian Sci. 2: 183-198.

Mesquita, S. \& Sousa, J. 2009. Bioclimatic mapping using geostatistical approaches: application to mainland Portugal. Int. J. Climatol. 29: 2156-2170.
Moran, P.A.P. 1950. Notes on continuous stochastic phenomena. Biometrika 37: 17-33.

Moreno-Rueda, G., Pizarro, M. \& Ontiveros, D. 2009. The coexistence of the eagles Aquila chrysaetos and Hieraaetus fasciatus increases with low human population density, intermediate temperature, and high prey diversity. Ann. Zoo. Fenn. 46: 283-290.

Nams, V.O., Mowat, G. \& Panian, M.A. 2006. Determining the spatial scale for conservation purposes - an example with Grizzly Bears. Biol. Conserv. 128: 109-119.

Nudda, G., Botti, P. \& Tola, F. 2015. Rapporto sugli incendi boschivi e rurali in Sardegna. Anno 2014. Eds. Regione Autonoma della Sardegna - Assessorato alla Difesa dell'Ambiente \& Centro Euro-Mediterraneo sui Cambiamenti Climatici, 74 pp.

Ontiveros, D. \& Pleguezuelos, J.M. 2003. Physical, environmental and human factors influencing productivity in Bonelli's Eagle Hieraaetus fasciatus in Granada (SE Spain). Biodivers. Conserv. 12: 1193-1203.

Ontiveros, D., Pleguezuelos, J.M. \& Caro, J. 2005. Prey density, prey detectability and food habits: the case of Bonelli's eagle and the conservation measures. Biol. Conserv. 1: 19-25.

PAF. 2014. Quadro di Azioni Prioritarie (Prioritised Action Framework, PAF) per la Rete Natura 2000 della Regione Sardegna Periodo di programmazione 2014-2020. Assessorato della Difesa dell'ambiente, Direzione Generale dell'Ambiente, servizio tutela del territorio.

Pedrini, P. \& Sergio, F. 2001. Golden Eagle Aquila chrysaetos density and productivity in relation to land abandonment and forest expansion in the Alps. Bird Study 48: 194-199

Penteriani, V., Balbontìn, J. \& Ferrer, M. 2003. Simultaneous effects of age and territory quality on fecundity in Bonelli's Eagle. Hieraaetus fasciatus. Ibis 145: E77-E82.

Raganella-Pelliccioni, E., Nardelli, R. \& Serra, L. 2018. The reintroduction of Bonelli's Eagle (Aquila fasciata Vieillot 1822) in Sardinia: feasibility plan. Action A1, LIFE PROJECT 'AQUILA a-LIFE', March 2018.

R Core Team. 2020. R: A language and environment for statistical computing. $\mathrm{R}$ Foundation for Statistical Computing, Vienna, Austria. https://www.R-project.org/.

Real, J. 2004. Águila-azor Perdicera. In Madroño, A., Moreno-Rueda, G., González, C. \& Atienza, J.C. (eds) Libro rojo de las aves de España, 154-157. Dirección General para la Biodiversidad-SEO/Birdlife, Madrid, Spain.

Robertson, M.P., Peter, C.I. \& Villet, M.H. 2003. Comparing models for predicting species' potential distribution: a case study using correlative and mechanistic predictive modelling techniques. Ecol. Model. 164: 153-167.

Román-Muňoz, A.R., Real, R. \& Barbosa, A.M. 2005. Modelling the distribution of Bonelli's eagle in Spain: implications for conservation planning. Divers. Distrib. 11: 477-486.

Rondinini, C., Battistoni, A. \& Peronace, V. 2013. Lista Rossa IUCN dei Vertebrati Italiani. Comitato Italiano IUCNe Ministero dell'Ambiente e della Tutela del Territorio e del Mare, Roma.

Ruiu, D. 2017. Status of Golden Eagle's nesting pairs in Sardinia. Avocetta 41: 89-93.

Rushton, S.P., Ormerod, S.J. \& Kerby, G. 2004. New paradigms for modelling species distributions? J. App. Ecol. 41: 193-200. 
Rutledge, D. 2003. Landscape indices as measures of the effects of fragmentation: can pattern reflect process? Doc Science Internal Series 98. Department of Conservation, Wellington, New Zealand.

Sarà, M. \& Di Vittorio, M. 2003. Factors influencing the distribution, abundance and nest-site selection of an endangered Egyptian vulture (Neophron percnopterus) population in Sicily. Animal Conserv. 6: 317-328.

Schenk, H. 1976. Analisi della situazione faunistica in Sardegna. Uccelli e Mammiferi. In Fauna, S.O.S. (ed) Animali in pericolo in Italia, 502-503. WWF-Italia, Camerino.

Schenk, H. 1995. Status faunistico e di conservazione dei vertebrati (Amphibia, Reptilia, Aves, Mammalia) riproducentisi in Sardegna, 1900-1993. Pp. 41-95. In: Atti $1^{\circ}$ Conv. Reg. Fauna selvatica Sardegna.

Sergio, F., Pedrini, P. \& Rizzoli, F. 2006. Adaptive range selection by Golden Eagles in a changing landscape: a multiple modelling approach. Biol. Conserv. 133: 32-41.

Singh, N.J., Moss, E. \& Hipkiss, T. 2016. Habitat selection by adult Golden Eagles Aquila chrysaetos during the breeding season and implications for wind farm establishment. Bird Study 63: 233-240.

Sirigu, G., Serra, L. \& Di Vittorio, M. 2019. Preliminary data on Golden Eagle (Aquila chrysaetos) diet in southern Sardinia. Avocetta 43: 86-89.

Steenhof, K., Kochert, M.N. \& McDonald, T.L. 1997. Interactive effects of prey and weather on Golden Eagle reproduction. J. Anim. Ecol. 66: 350-362.

Stefânescu, D.M. \& Bâlescu, D.C. 2019. Predicting the distribution of Golden Eagle (Aquila chrysaetos) in Romania using the Maxent method. North-West J Zool. 15: 67-74.

Tapia, L., Domínguez, J. \& Rodríguez, L. 2007. Modelling habitat use and distribution of Golden Eagles Aquila chrysaetos in a low-density area of the Iberian Peninsula. Biodivers. Conserv. 16: 3559-3574.
Tjernberg, M. 1983. Prey abundance and reproductive success of the Golden Eagle Aquila chrysaetos in Sweden. Holarct. Ecol. 6: 17-23.

Watson, J. \& Dennis, R.H. 1992. Nest site selection by Golden Eagles Aquila chrysaetos in Scotland. Br. Birds 85: $469-481$.

Watson, J. 1991. The Golden Eagle and pastoralism across Europe. In Curtis, D.J., Bignal,, E.M. \& Curtis, M.A. (eds) Birds and Pastoral Agriculture in Europe, 56-57. JNCC, Peterborough.

Watson, J. 1992. Golden Eagle Aquila chrysaetos breeding success and afforestation in Argyll. Bird Study 39: 203-206.

Watson, J. 1997. The Golden Eagle. T \& D Poyser, London, UK.

Watson, J. 2010. The Golden Eagle, 2nd edn. Yale University Press, New Haven, Connecticut, USA.

Watson, J., Fielding, A.H. \& Whitfield, D.P. 2003. Golden eagle breeding performance in relation to climate in western Scotland during the period 1981-2000. In Thompson, D.B.A., Redpath, S., Fielding, A.H., Marquiss, M. \& Galbraith, C.A. (eds) Birds of Prey in a Changing Environment, 149-161. The Stationery Office, Edinburgh.

Watson, J., Langslow, D.R. \& Rae, S.R. 1987. The Impact of Land Use Change on Golden Eagles in the Scottish Highlands. CSD Report 720. Nature Conservancy Council, Peterborough.

Whitfield, D.P., McLeod, D.R.A. \& Fielding, A.H. 2001. The effects of forestry on golden eagles on the island of Mull, western Scotland. J. Appl. Ecol. 38: 1208-1220.

Whitfield, D.P., Fielding, A.H. \& McLeod, D.R.A. 2004. Modelling the effects of persecution on the population dynamics of golden eagles in Scotland. Biol. Conserv. 119: 319-333.

Whitfield, D.P., Fielding, A.H. \& Gregory, M.J.P. 2007. Complex effects of habitat loss on Golden Eagles Aquila chrysaetos. Ibis 149: 26-36. 